\title{
Mechanism of Action of Coumarin against Candida albicans by SEM/TEM Analysis
}

\author{
Gunawan Pamudji Widodo $^{1}$, Elin Yulinah Sukandar ${ }^{2}$, I Ketut Adnyana ${ }^{2} \&$ \\ Sukrasno ${ }^{3}$ \\ ${ }^{1}$ Faculty of Pharmacy, Universitas Setia Budi, Jalan Letjen. Sutoyo, Mojosongo \\ Surakarta, Jawa Tengah 57127, Indonesia \\ ${ }^{2}$ Pharmacology-Clinical Pharmacy, School of Pharmacy, Institut Teknologi Bandung, \\ Jalan Ganesha 10 Bandung, Jawa Barat 40132, Indonesia \\ ${ }^{3}$ Biological Chemistry, School of Pharmacy, Institut Teknologi Bandung, \\ Jalan Ganesha 10 Bandung, Jawa Barat 40132, Indonesia \\ Email: gunawanpamudji@yahoo.com
}

\begin{abstract}
The aim of this study was to identify the antifungal activity of coumarin isolated from Ageratum conyzoides L. leaves and to observe its influence on Candida albicans cells by scanning electron microscope (SEM) and transmission electron microscope (TEM). Antifungal activity testing with the disk diffusion method showed coumarin was active toward pathogenic fungus Candida albicans with an MIC value of coumarin of $125 \mu \mathrm{g} \mathrm{mL}^{-1}$. The results show that this compound damaged the cell by pores formation on the cell wall. Death of cells occurred due to leakage and necrosis of cytoplasmic content.
\end{abstract}

Keywords: Ageratum leaves; antifungal activity; Candida albicans; coumarin; SEM; TEM.

\section{$1 \quad$ Introduction}

Coumarin found in the plant world belongs to the families of Apiaceae, Fabaceae, Asteraceae, Rutaceae, Saxifragaceae, and Thymelaceae. Coumarin compounds from Ageratum conyzoides L., including coumarin (1,2benzopyrone), have been reported. Coumarin is known for its pharmacological promiscuity because of its extensive bioactivities, such as its anticoagulant, estrogenic, anti-dermal photosensitizing, antibiotic, anti-helmintic, sedative and hypnotic, analgesic and hypothermal activities [1]. Coumarins are known as potential growth inhibitors of bacteria and fungi. Both natural and synthetic coumarins inhibit the growth of the common microorganisms Candida albicans, Escherichia coli and Staphylococcus aureus [2]. Some coumarin polyacetylene derivatives display antimycobacterial activity, and antifungal activity of Argentum (I)-coumarin complexes against pathogenic yeast Candida albicans has been reported; it was showed that these complexes lowered the ergosterol content of the fungal cells and increased the transmembrane leakage of amino acids [3].

Received November $10^{\text {th }}, 2011$, Revised February $9^{\text {th }}, 2012$, Accepted for publication April $11^{\text {th }}, 2012$. Copyright (C) 2012 Published by LPPM ITB, ISSN: 1978-3043, DOI: 10.5614/itbj.sci.2012.44.2.4 
Candida albicans occurs naturally as a commensal of mucous membranes and in the digestive tract of humans and animals. It is reported as a causative agent of all types of candidiasis, such as thrush, vaginal and other type of infections [4].

The objectives of this research were to identify the antifungal activity of coumarin and to observe the influence of this compound on Candida albicans cells by SEM and TEM.

\section{Materials and Methods}

\subsection{Materials}

The C. albicans fungus was obtained from the School of Pharmacy, ITB (Institut Teknologi Bandung), Bandung, Indonesia. Fresh leaves of Ageratum conyzoides were collected from an herbal medicinal garden in Lembang, West Java, Indonesia. Taxonomic determination was conducted by the Herbarium Bandungense, School of Life Sciences and Technology, ITB, Indonesia.

\subsection{Methods}

\subsubsection{Isolation of Coumarin}

Coumarin has been isolated from acetone fraction of the ethanol extract of Ageratum conyzoides leaves, as described in a previous report [5].

\subsubsection{Antifungal Activity Test}

Coumarin $(0.01 \% \mathrm{w} / \mathrm{v})$ was tested for antifungal activity against $C$. albicans by disk diffusion using potato dextrose agar (PDA) as medium, with an incubation temperature of $22-25{ }^{\circ} \mathrm{C}$ for $24-48$ hours. Dichloromethane was used as the negative control [6]. The antifungal activity of coumarin was compared to miconazole nitrate BPFI as a fungistatic standard medicine against $C$. albicans, to predict the properties of coumarin as a fungicide or fungistatic. Coumarin and miconazole nitrate at a concentration of $100 \mu \mathrm{g} \mathrm{mL}^{-1}$ in dichloromethane was tested by disk diffusion and the inhibition zone was observed.

\subsubsection{Minimum Inhibitory Concentration (MIC) Determination}

Antifungal activity was evaluated by determining the MIC value, i.e the lowest concentration of the compound that will inhibit the visible growth of a microorganism after overnight incubation. The MIC of coumarin against $C$. albicans was determined by making serial concentrations (1000, 500, 250, 125, $62.5,31.25 \mu \mathrm{g} \mathrm{mL}^{-1}$ ) in dichloromethane. For each experiment, both antifungal activity test and MIC determination were done in four replications. 


\subsubsection{Sample Analysis with Scanning Electron Microscope}

Scanning Electron Microscopy (SEM) was carried out using a JEOL, type JSM6360 LA, Analytical Scanning Electron Microscope. SEM preparation for the control cells was done by harvesting the inoculated cells in Saburoud Dextrose Broth (SDB) after 24 hours of incubation in a shaking incubator at a temperature of $22-25{ }^{\circ} \mathrm{C}$. After agitation, the supernatant was added to a prefixative solution ( $2 \%$ glutaraldehide in Na-cocodilate buffer), then resuspended with gentle agitation and fixed in the prefixative solution for several hours at $4{ }^{\circ} \mathrm{C}$. The sediment was then washed again with a phosphate buffer solution $(\mathrm{pH} \mathrm{7.4)}$ and $1 \%$ OsO4 was added in the phosphate buffer solution ( $\mathrm{pH} \mathrm{7.4)} \mathrm{for} \mathrm{post-fixation,} \mathrm{and} \mathrm{subsequently} \mathrm{the} \mathrm{cells} \mathrm{were} \mathrm{resuspended}$ for 1 hour at $4{ }^{\circ} \mathrm{C}$. The cells were dehydrated by adding a series of EtOH $(50 \%$, $75 \%, 88 \%, 94 \%$ and absolute EtOH) and then suspended in t-butanol. The cell suspension was dropped onto a small piece of chilled coverslip and freeze-dried. The dried cells were observed under the SEM after metal coating.

The SEM preparation for the treated cells was done by harvesting the inoculated cells on a mixture of coumarin solution $(0.25 \% \mathrm{w} / \mathrm{v})$ in dichloromethane and Saburoud Dextrose Broth (SDB).

\subsubsection{Sample Analysis with Transmission Electron Microscope}

Transmission electron microscopy (TEM) was carried out using a microtome Reichert Ultracut S Leica, JEM-1010 JEOL Electron Microscope. TEM preparation was done with the same method as SEM preparation, but the dehydration process was performed in a different series of $\mathrm{EtOH}(10 \%, 20 \%$, up to $100 \%)$. The dried cells were infiltrated in a mixture of EtOH with propylene oxyde (2:1, 1:1, 1:2 and 0:1) and infiltrated in resin $(50 \%, 75 \%$ and $100 \%$ resin in propylene oxyde). The infiltrated cells were embedded and cured to yield the solid form of the cells, which were then ready for section with the microtome. The section (nm) was stained and observed with TEM.

\section{$3 \quad$ Results and Discussion}

Coumarin had been isolated from acetone fraction of A. conyzoides $\mathrm{L}$. leaves and showed antifungal activity against $C$. albicans. Further assay showed that dichloromethane as a control solvent had no significant effect. Coumarin showed a clear inhibition zone up to 72 hours of incubation, while miconazole nitrate gave only 24 hours. This observation suggests that coumarin acts as a fungicide against $C$. albicans. The MIC value of coumarin was $125 \mu \mathrm{g} \mathrm{mL}^{-1}$ [5]. 


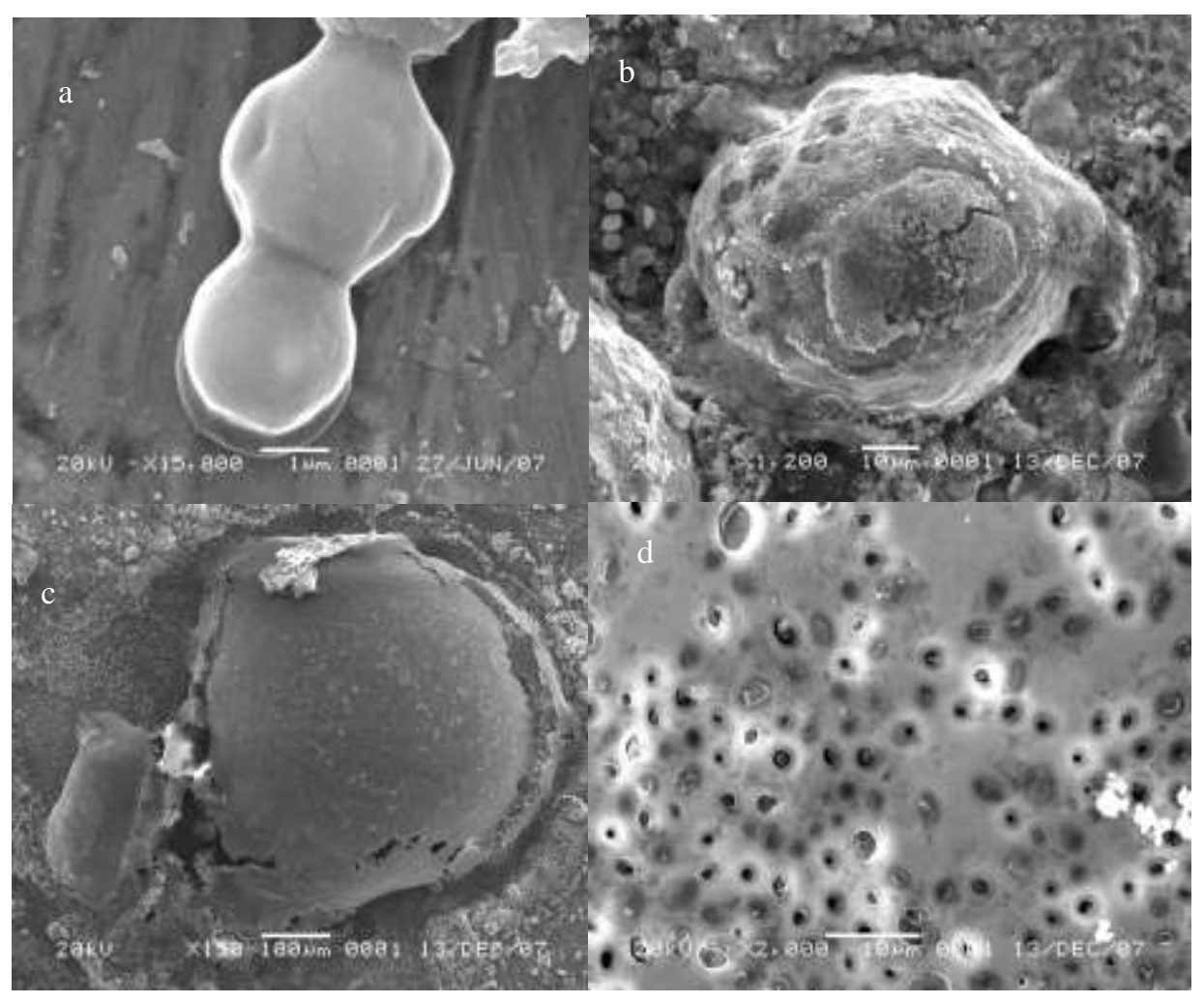

Figure 1 Influence of coumarin on C. albicans cells. (a) C. albicans control cells examined by SEM show a smooth surface (x15,000); (b) cell after treatment; the surface has changed from smooth to rough, covered by some material that seems to be derived from broken cells (x 1,200); (c) cracked cell after treatment (x 150); (d) enlarged cracked cell, showing numerous pores in its wall (x 2,000).

Electron Microscopy (EM) is one of many methods available for visual inspection of fungal strains. The effects of potential antifungal extracts from natural sources can also be evaluated by using EM methods. SEM is advantageous over several other microscopy methods as it is three-dimensional and almost the whole of the specimen is sharply focused [7]. The influence of coumarin on $C$. albicans cells as observed by SEM can been seen in Figure 1. The SEM observations show that $1000 \mu \mathrm{g} \mathrm{mL}^{-1}$ coumarin in dichloromethane has damaged most of the cells by forming pores in the cell's wall and broken the cells (Figures 1c and d). This agrees with research by Thati, et al. [3], which suggests that $\mathrm{Ag}(\mathrm{I})$-coumarin complexes lower the ergosterol content of fungal cells. Ergosterol serves as a bioregulator for membrane fluidity and consequently of membrane integrity in fungal cells. Inhibition of ergosterol synthesis leads to the depletion of the cells, resulting in the formation of a 
plasma membrane with an altered structure and function [8]. This abnormal structure and function may increase transmembrane leakage of amino acids and other cytoplasmic contents. This mechanism of action is different from that of other antifungal extracts from medicinal plants. Shalgal, et al. [9] reported that morphological changes were observed in the $C$. albicans during treatment with a Swietenia mahogani seed extract at various exposure times. The cells started to shrink, and then clumped together before they were completely destroyed by the extract.

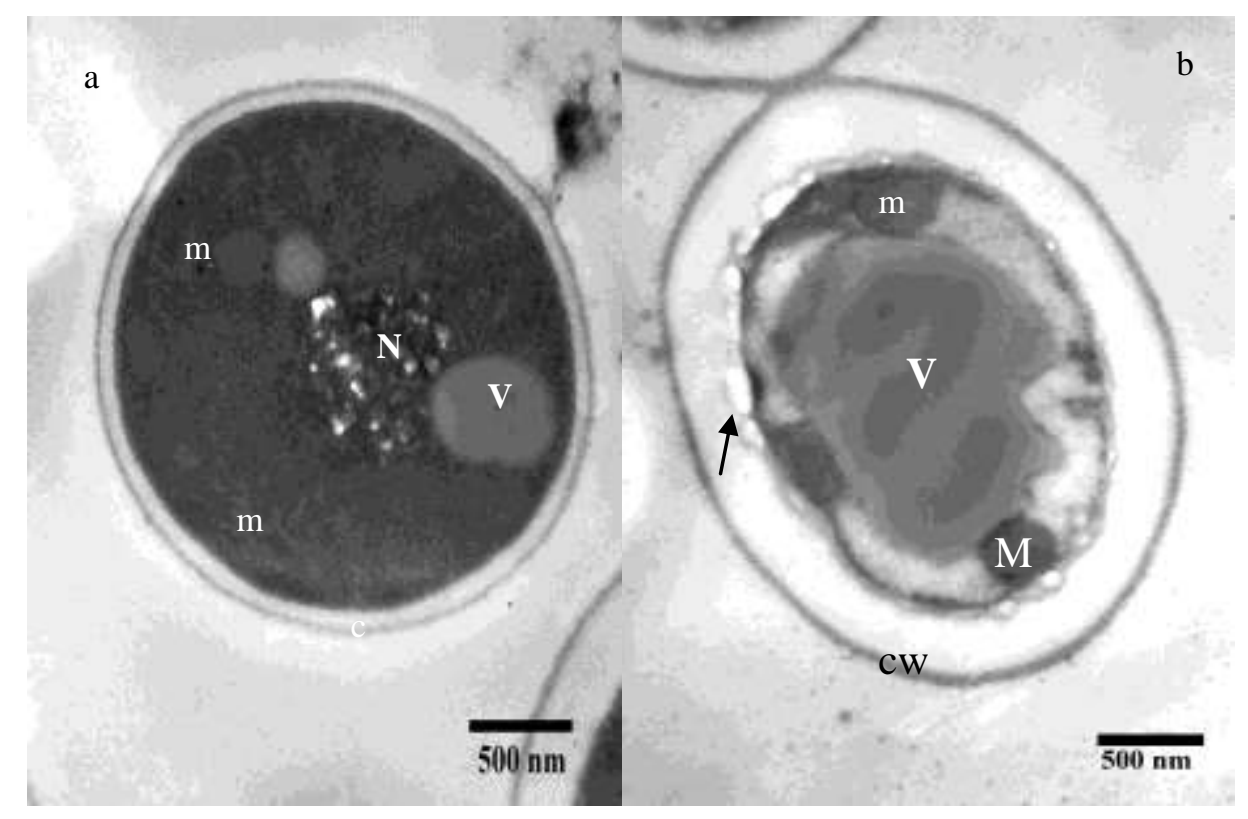

Figure 2 The control cell (a) examined by TEM. The cell presents a regularly outlined cell wall $(\mathrm{cw})$, mitochondria $(\mathrm{m})$, nucleus $(\mathrm{N})$ and small vacuola $(\mathrm{V})$. The treatment cell (b) shows that the outline of the cell wall and the cell wall have become thicker, while the peripheral cytoplasm contains numerous small holes (arrow). The treatment cell shows reduced cytoplasmic density, necrosis of cytoplasmic contents, and also an abnormal shape of the vacuole, which has become broader than the vacuole in the normal cell.

Further confirmation of the SEM findings can be obtained by TEM study. The untreated $C$. albicans cells as examined by TEM shows the typical morphology of Candida with a uniform central density, a typically structured nucleus, and a cytoplasm with several elements of the endomembrane system, enveloped by a regular cell wall [10]. In this study the control cell examined by TEM presents a regular cell wall $(\mathrm{cw})$, mitochondria $(\mathrm{m})$, nucleus $(\mathrm{N})$ and vacuole $(\mathrm{V})$. Mitochondria were observed near the periphery of the cytoplasm and in close proximity to the nucleus (Figure 2). After coumarin treatment, most cells were 
not different from the control cells in shape or size, but the inside of the cells showed great difference. The outline of the cell wall became thicker after the treatment. This might be due to the accumulation of membranous material in the surrounding of the cell wall surface. The cell wall also became thicker, which may be caused by the increase of transmembrane leakage of amino acids and other cytoplasmic contents, while the peripheral cytoplasm now contained numerous small holes. This phenomenon reduces the cytoplasmic density and shows necrosis of cytoplasmic content. An abnormal shape of the vacuola was observed: broader than in the normal cell. This mechanism is similar to that of the Euphorbia hirta extract, as reported by Basma, et al. [10]. The cell membrane and cell walls were altered after $24 \mathrm{~h}$ of extract exposure, while the cytoplasmic volume decreased with structural disorganization within the cell cytoplasm. The SEM and TEM images after coumarin show effects resembling those induced by poliene antifungal agents on the cell wall of Candida albicans. However, the exact mechanism of action of coumarin has yet to be examined.

\section{Conclusion}

The results of this research show that a coumarine compound damages the Candida albicans cells by pores formation in the cell wall. Death of cells occurred due to leakage and necrosis of cytoplasmic content.

\section{Acknowledgements}

We wish to thank the Ministry of National Education of the Republic Indonesia (BPPs) and ITB Research Grant 2007 for their financial support, and Elfahmi, Ph.D. and Kusnandar A., Ph.D., School of Pharmacy, Institut Teknologi Bandung, for reviewing this manuscript.

\section{References}

[1] Mladenović, M., Vuković, N., Sukdolak, S. \& Solujić, S., Design of Novel 4-Hydroxy-chromene-2-one Derivatives as Antimicrobial Agents, Molecules, 15, pp. 4294-4308, 2010.

[2] Ming, L.C., Ageratum conyzoides: A Tropical Source of Medicinal and Agricultural Products, Perspectives on New Crops and New Uses, J. Janick (ed.), ASHS Press, Alexandria, pp. 469-473, 1999.

[3] Thati, B., Noble, A., Rowan, R., Creaven, B.S., Walsh, M., McCann, M., Egan, D. \& Kavanagh, K., Mechanism of Action of Coumarin and Silver (I) Coumarin Complexes Against the Pathogenic Yeast Candida Albicans, Toxicology in Vitro, 21(5), pp. 801-808, 2007.

[4] Schaechter, M., Ingraham, J.L. \& Neidhardt, F.C., Microbe, ASM Press, Washington, pp. 315-316, 2006. 
[5] Widodo, G.P., Sukandar, E.Y., Sukrasno \& Adnyana, I.K., A Coumarin from Ageratum Leaves (Ageratum conyzoides L.), International J. of Pharmacology, 1(4), pp. 56-59, 2008.

[6] Liu, Y., Tortora, G., Ryan, M.E., Lee, H. \& Golub, L.M., Potato Dextrose Agar Antifungal Susceptibility Testing for Yeasts and Molds: Evaluation of Phosphate Effect on Antifungal Activity of CMT-3, Antimicrob. Agents Chemother., 46(5), pp. 1455, 2002.

[7] Sasidharan, S., Zuraini, Z., Yoga, L.L., \& Suryani, S., Fungicidal Effect and Oral Acute Toxicity of Psophocarpus Tetragonolobus Root Extract, Pharmaceutical Biology, 46, pp. 261-265, 2008.

[8] Ghannoum, M.A. \& Rice, L.B., Antifungal Agents: Mode of Action, Mechanism of Resistance, and Correlation of These Mechanisms with Bacterial Resistance, Clin. Microbiol. Rev., 12 (4), pp. 501-517, 1999.

[9] Sahgal, G., Ramanathan, S., Sasidharan, S., Mordi, M.N., Ismail, S. \& Mansor, S.M., In Vitro and In Vivo Anticandidal Activity of Swietenia Mahogani Methanolic Seed Extract, Tropical Biomedicine, 28(1), pp. 132-137, 2011.

[10] Basma, A.A, Zuraini, Z., \& Sasidharan, S., A Transmission Electron Microscopy Study of The Diversity of Candida Albicans Cells Induced by Euphorbia Hirta L. Leaf Extract in Vitro, Asian Pacific Journal of Tropical Biomedicine, pp. 20-22, 2011. 